\title{
Cerita dan Lagu Rumah Sederhana untuk Anak Usia Dini Berbasis Media Audio Visual
}

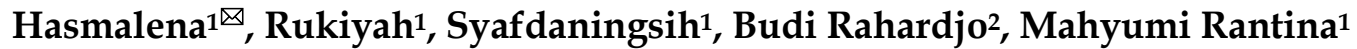 \\ Pendidikan Guru Pendidikan Anak Usia Dini, Universtias Sriwijaya, Indonesia(1) \\ Pendidikan Guru Pendidikan Anak Usia Dini, Universitas Mulawarman, Indonesia(2) \\ DOI: $10.31004 /$ obsesi.v6i4.2104
}

\begin{abstract}
Abstrak
Penelitian ini bertujuan untuk menghasilkan cerita dan lagu berbasis tema pada anak usia dini berbasis media audio visual. Jenis penelitian yang digunakan adalah penelitian dan pengembangan dengan menggunakan model ADDIE. Tahapan penelitian yang dilakukan adalah analisis kebutuhan, perancangan desain, pengembangan produk, evaluasi dan implementasi. Dalam penelitian ini dilakukan hingga tahap evaluasi oleh validator materi dan media. Teknik pengumpulan data menggunakan lembar angket. Berdasarkan penilaian validator, hasil pengembangan cerita dan lagu rumah sederhana sangat valid dengan memperoleh persentase sebesar $96,25 \%$ dan hasil validasi media dari validator memperoleh nilai persentase sebesar $93,17 \%$ dengan kategori sangat valid sehingga rata-rata hasil validasi media dan validasi materi memperoleh nilai persentase sebesar $94,71 \%$ dengan kategori sangat valid artinya media audio visual cerita dan lagu rumah sederhana untuk anak usia dini sangat valid untuk diujikan dan diimplementasikan pada subjek penelitian ditinjau dari media visual, audio, bahasa, pemrograman, tampilan dan kelayakan isi.
\end{abstract}

Kata kunci: cerita; lagu; rumah sederhana; paud

\begin{abstract}
This study aims to produce theme-based stories and songs in early childhood based on audiovisual media. The type of research used is research and development using the ADDIE model. The stages of the research carried out was needs analysis, design design, product development, evaluation and implementation. In this study, it was carried out to the evaluation stage by material and media validators. The data collection technique used a questionnaire sheet. Based on the validator's assessment, the results of the development of simple house stories and songs are very valid by obtaining a percentage of $96.25 \%$ and the results of media validation from the validator obtaining a percentage value of $93.17 \%$ with a very valid category so that the average results of media validation and material validation obtain a value the percentage of $94.71 \%$ with a very valid category means that audio-visual media stories and simple house songs for early childhood are very valid to be tested and implemented on research subjects in terms of visual media, audio, language, programming, appearance and content feasibility.
\end{abstract}

Keywords: stories; songs; simple houses; early childhood

Copyright (c) 2022 Hasmalena, et al.

$\triangle$ Corresponding author :

Email Address hasmalena@fkip.unsri.ac.id (Palembang, Indonesia)

Received 17 November 2021, Accepted 15 January 2022, Published 28 January 2022 


\section{PENDAHULUAN}

Perkembangan adalah suatu proses perubahan dimana anak belajar untuk menguasai tingkat yang lebih tinggi dari berbagai aspek. Salah satu aspek perkembangan yang penting adalah aspek perkembangan bahasa. Usia anak-anak adalah usia yang paling tepat untuk mengembangkan bahasa. Perkembangan bahasa pada anak usia dini meliputi empat perkembangan yaitu mendengarkan, berbicara, membaca dan menulis (Rusniah, 2017). Pengembangan ini harus dilakukan secara seimbang agar diperoleh perkembangan membaca dan menulis yang optimal. Pengembangan bahasa untuk anak TK berdasarkan standar acuan pendidikan anak usia dini no. 58 Tahun 2009, mengembangkan tiga aspek, yaitu bahasa menerima, bahasa ekspresi, dan literasi.

Pembelajaran di TK erat kaitannya dengan kegiatan mendongeng dan bernyanyi. Anak-anak di zaman ini sudah begitu dimanjakan dengan kemajuan teknologi sehingga memudahkan anak-anak dalam mengakses informasi sehingga anak-anak lebih memilih lagu dewasa daripada lagu anak-anak. Perkembangan cerita dan lagu anak sudah sampai pada tahap yang mengkhawatirkan dan tidak mendukung perkembangan anak sesuai usianya. Program pembentukan perilaku bertujuan untuk mempersiapkan anak sedini mungkin untuk mengembangkan sikap dan perilaku berdasarkan nilai-nilai moral Pancasila dan Agama had (H. Putri, 2017). Sedangkan program pengembangan kemampuan dasar adalah segala kegiatan yang ditujukan untuk mencapai kemampuan tertentu yang sesuai dengan tahap perkembangan anak. Kemampuan tersebut meliputi kreativitas, daya pikir, keterampilan, kemampuan fisik, dan bahasa. Untuk membantu guru dalam melaksanakan berbagai program kegiatan pembelajaran di PAUD/TK, telah ditetapkan berbagai tema yang dapat dijadikan acuan dalam pengembangan selanjutnya.

Pada saat perkembangan ilmu pengetahuan dan teknologi saat ini sangat berpengaruh terhadap kehidupan manusia dan mengalami perkembangan yang sangat pesat. Oleh karena itu, dibutuhkan kemampuan untuk memperoleh, dan memanfaatkan ilmu pengetahuan dan teknologi dengan sebaik-baiknya yang dapat meningkatkan mutu pendidikan. Hal yang paling menentukan dalam mencapai mutu pendidikan adalah proses pembelajaran yang dilakukan, salah satunya adalah pembelajaran untuk meningkatkan kemampuan komunikasi anak. Pendidikan anak usia dini saat ini sangat diperlukan karena kebutuhan akan kualitas pendidikan anak sangat mempengaruhi perilakunya. Pernyataan ini juga didukung oleh adanya perubahan pandangan dalam dunia pendidikan dan berbagai perkembangan ilmu pengetahuan, teknologi, dan seni yang berdampak pada berbagai aspek pendidikan, termasuk kebijakan pendidikan.

Menurut Fiah $(2017,33)$ jika pada awal kemerdekaan fokus perhatian pemerintah lebih pada pendidikan dasar, menengah, dan tinggi, maka perlahan setelah itu, perhatian pemerintah juga terfokus pada pendidikan sebelum jenjang pendidikan dasar, yaitu PAUD. Media pembelajaran diharapkan dapat menunjang pembelajaran agar lebih mudah dalam menyampaikan isi atau materi pembelajaran. Sebenarnya ada berbagai macam media pembelajaran yang dapat digunakan sebagai media pembelajaran, salah satunya adalah media audio visual.

Berdasarkan hasil observasi di Taman Kanak-Kanak di Palembang, Indonesia, terdapat permasalahan yaitu anak tidak mampu dan kurang aktif dalam memahami sebuah cerita di depan kelas ketika guru memintanya untuk mendongeng. Hal ini disebabkan kurang bervariasinya media yang digunakan seperti media audio visual atau Big book. Dari hasil observasi sehari-hari hanya menggunakan buku cerita kecil dan anak tidak terlibat langsung, hanya guru yang bercerita dan anak mendengarkan cerita tanpa ada kegiatan lain, cerita yang digunakan tidak menarik perhatian anak. Kumpulan lagu di TK Palembang menggunakan tema lagu anak-anak, baik lagu yang ada maupun lagu yang dimodifikasi sesuai tema. Pada saat observasi anak hanya duduk dan mendengarkan guru mendongeng menggunakan buku sehingga sangat membuat anak bosan, hal ini dibuktikan dengan 5 anak yang mendengarkan dan 10 anak yang ribut sendiri dan tidak mendengarkan. guru bercerita. Kemudian guru 
menyampaikan bahwa dengan adanya lagu dan nyanyian dapat memperlancar proses pembelajaran karena lagu dapat membuat anak cepat mengingat apa yang guru katakan dan lagu dapat memotivasi anak dalam kegiatan belajar. Hal ini sejalan dengan pendapat Widjanarko (2017) yang mengatakan bahwa bernyanyi dapat memudahkan anak dalam memahami pesan atau materi yang ingin disampaikan oleh guru.

Mengacu pada Pendidikan anak usia dini di era digital 4.0 sekarang sangat dekat dengan teknologi. Keterlibatan anak dengan teknologi mencapai lebih dari 50\% guru serta administrator mengatakan anak-anak menggunakan teknologi 5 hari seminggu di kelas mereka dan kurang dari 10\% dari mereka mengatakan anak-anak menggunakan teknologi kurang dari sekali seminggu (Rakimahwati et al., 2021). Hal tersebut membuktikan bahwa teknologi memiliki daya tarik bagi anak sehingga pendidik dapat mengikuti pembaharuan dengan memanfaatkan teknologi dalam merancang media pembelajaran yang kreatif dan inovatif tanpa menghilangkan nilai dan budaya terdahulu. Tujuan penggabungan ini ialah agar pembelajaran anak usia dini pada abad 21 ini dapat berkembang dan memperoleh keseimbangan pengetahuan dan sikap. Namun terkadang Guru mengabaikan dalam penggunaan media, padahal dengan menggunakan media pembelajaran khususnya media audio visual membuat anak termotivasi dalam belajar dan mudah penangkapan isinya oleh anak. Kebutuhan anak sangat membutuhkan media pembelajaran yang berjenis media audio visual yaitu video yang membuat suasana anak lebih menarik dan guru juga membutuhkan video untuk memudahkan guru dalam mempelajari kegiatan mendongeng untuk anak. Berdasarkan permasalahan diatas maka peneliti mencari alternatif lain dalam pembelajaran mendongeng anak agar tidak membosankan yaitu mendongeng dan bernyanyi berdasarkan tema akan dikemas ke dalam suatu bentuk media audio visual yang menarik perhatian anak dan peneliti mencoba untuk menciptakan produk berupa audio visual yang mampu menarik perhatian anak dan sesuai dengan karakteristik anak usia dini.

Berdasarkan hasil penelitian Ira Pergiwo Wati (2018) dengan judul "Pengembangan Buku Cerita Bergambar Berbasis Lagu Jawa Sebagai Media Penanaman Nilai Karakter Pada Anak Usia Dini di Kabupaten Pemalang" menyatakan bahwa penelitian yang dilakukan dapat membantu PAUD memahami karakter anak. cerita dan lagu dengan metode pembelajaran sambil bermain, sehingga dapat meningkatkan pemahaman dan menghilangkan kebosanan dalam kegiatan pembelajaran. Anak tidak hanya sekedar belajar tetapi dirangsang dengan kegiatan yang menarik menggunakan media audio visual berupa cerita dan lagu anak berbasis tema. Sehingga tujuan dari penelitian ini adalah untuk menghasilkan video audio visual cerita rumah sederhana yang valid dan praktis.

\section{METODOLOGI}

Penelitian dan pengembangan cerita rumah sederhana dan lagu anak usia dini berbasis tema melalui media pembelajaran audio visual mengacu pada penelitian dan pengembangan (R\&D). Tujuan penelitian dan pengembangan penelitian dan pengembangan (R\&D) adalah penelitian yang bertujuan untuk mengembangkan atau menghasilkan suatu produk tertentu. Dalam bidang pendidikan, penelitian dan pengembangan penelitian dan pengembangan adalah metode penelitian yang digunakan untuk membuat produk baru atau mengembangkan produk yang sudah ada dan kemudian divalidasi untuk digunakan dalam pendidikan dan pembelajaran. Produk yang dihasilkan dalam penelitian ini berupa pengembangan cerita dan lagu rumah sederhana melalui media pembelajaran audio visual. Tahapan dan pengembangan dalam penelitian ini mengacu pada model ADDIE (Analysis, Design, Development, Implementation, Evaluation). Penelitian ini hanya dilakukan hingga tahap validasi materi dan validasi media dikarenakan pada masa pandemi covid-19. Model penelitian ini mewujudkan model desain pembelajaran yang sistematis berdasarkan pertimbangan pengembangan untuk keserasian antara media yang dikembangkan dan kebutuhan siswa serta kelebihan dan kekurangan dari masing-masing model pengembangan, model pengembangan ADDIE dipilih dengan skema seperti bagan pada gambar 1 . 


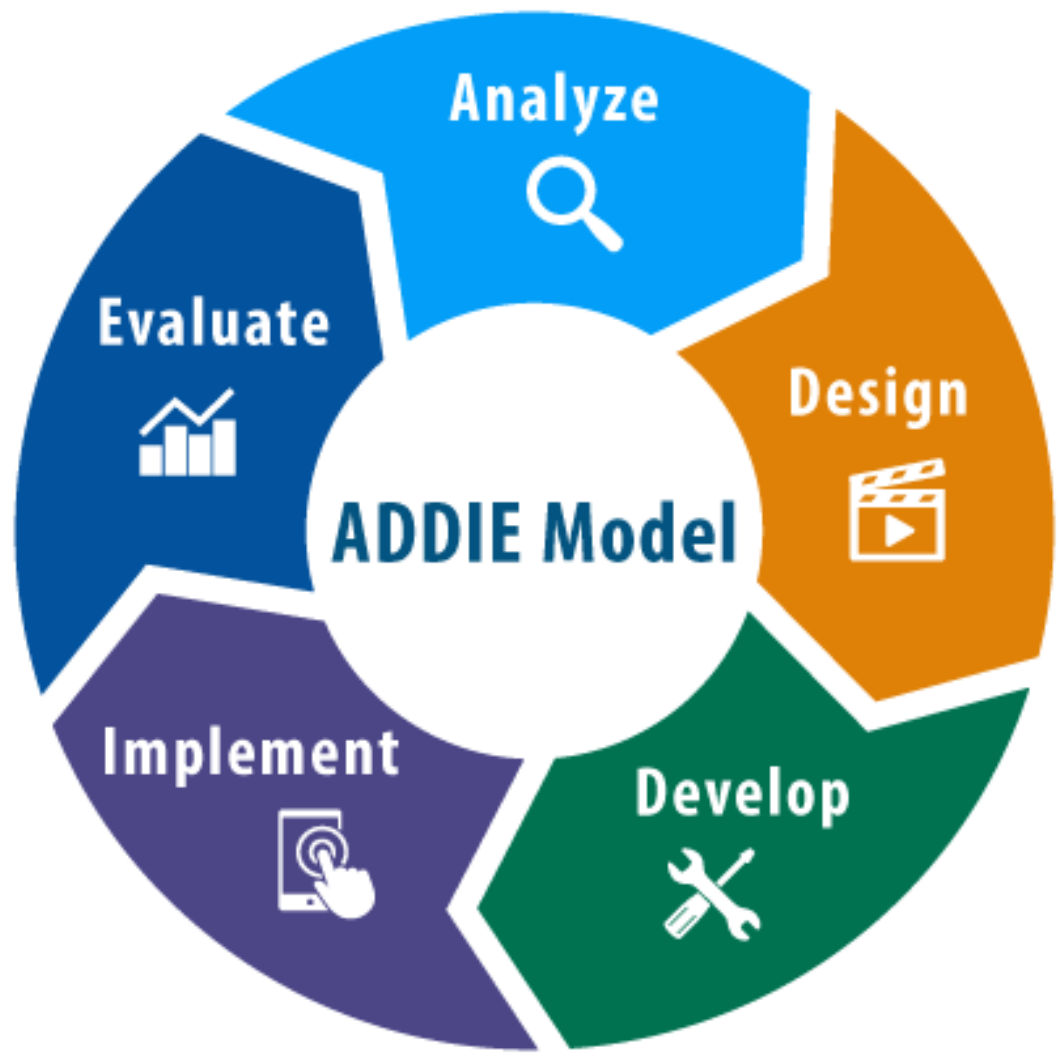

Gambar 1. Model ADDIE

Subjek penelitian (sumber data dan primer) dalam penelitian ini adalah guru, praktisi PAUD dan orang tua yang terdiri dari tinjauan ahli yang terdiri dari 2 orang validator untuk meninjau produk secara produk dan secara materi/konten dengan Objek penelitian ini merupakan media pembelajaran audio visual yang akan diujicobakan oleh guru kepada PAUD dengan dua tahap yaitu tahap uji coba pendampingan dan tahap uji coba kelompok kecil untuk melihat kepraktisan produk yang dikembangkan.

\section{HASIL DAN PEMBAHASAN}

\section{Analisis Kebutuhan}

Langkah pertama yang harus dilakukan dalam penelitian ini adalah menganalisis kebutuhan, yang bertujuan untuk mengetahui kebutuhan orang tua dan guru PAUD tentang media pembelajaran audio visual. Berdasarkan kenyataan di lapangan, belum ada media pembelajaran audio visual berbasis tema dengan metode cerita dan lagu untuk anak usia dini dan belum menyesuaikan karakteristik anak berdasarkan kurikulum 13 dengan materi khususnya aspek perkembangan anak usia dini. bagi orang tua dan guru PAUD di Kota Palembang. Pengumpulan data dilakukan pada langkah ini dengan menggunakan angket.

\section{Desan Produk dan Pengembangan}

Produk yang dikembangkan dalam penelitian ini adalah media audio visual, cerita dan lagu anak berbasis tema. Tema yang dikembangkan seperti Tema Lingkungan Saya, Tema Alam Semesta, Tema Tumbuhan, Tema Hewan. Pemilihan tema ini didasarkan pada hasil analisis kebutuhan yang dilakukan peneliti terhadap guru dan orang tua. Pada tahap awal peneliti merumuskan cerita berdasarkan tema yang telah disusun, kemudian membuat lagu yang sesuai dengan isi cerita yang telah dibuat dalam skenario dan mengembangkan media audio visual berupa video cerita dan lagu. Perancangan dan langkah-langkah pengembangan produk Video story dan lagu berbasis tema dapat dilihat pada tabel 1. 
Tabel 1 Prototipe produk media audio visual

\begin{tabular}{|c|c|c|c|}
\hline No & Langkah-Langkah & Hasil & Deskripsi \\
\hline \multirow[t]{2}{*}{1} & $\begin{array}{l}\text { Merumuskan Skenario } \\
\text { Cerita (cerpen 1) }\end{array}$ & 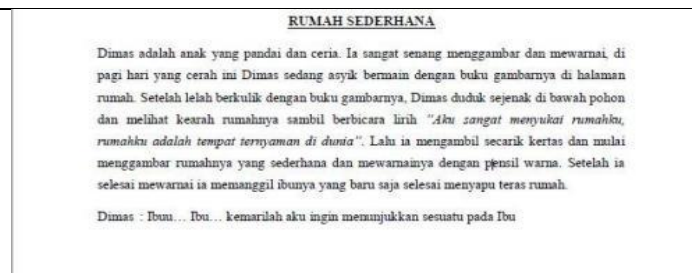 & $\begin{array}{l}\text { Cerita Rumah } \\
\text { Sederhana, } \\
\text { Lingkunganku } \\
\text { Tema, sub tema : } \\
\text { Lingkungan } \\
\text { rumahku }\end{array}$ \\
\hline & & 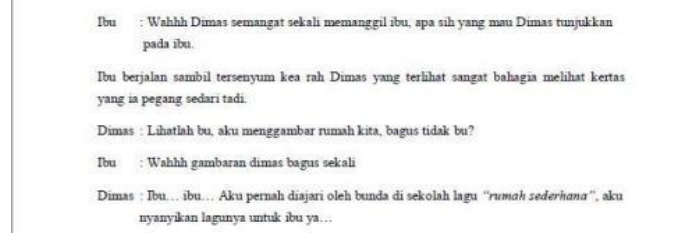 & \\
\hline 2 & $\begin{array}{l}\text { Membuat Lagu dari } \\
\text { cerpen } 1\end{array}$ & 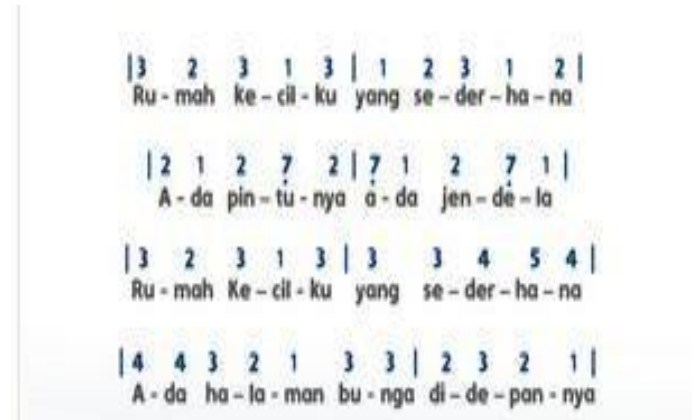 & $\begin{array}{l}\text { Lagu rumah } \\
\text { sederhanaku } \\
\text { dikembangkan } \\
\text { dengan nada dan } \\
\text { lirik yang sesuai } \\
\text { dengan tema }\end{array}$ \\
\hline 3 & $\begin{array}{l}\text { Video Pengembangan } \\
\text { Rumah Sederhana } \\
\text { Sederhana cerita dan } \\
\text { lagu }\end{array}$ & $\begin{array}{l}\text { https:/ / drive.google.com/file/d/1a69Z- } \\
\text { JtyD5zsd085fkHLEL96D1NtYPiK/view?usp }\end{array}$ & $\begin{array}{l}\text { Cerita video } \\
\text { animasi dan lagu } \\
\text { rumah sederhana }\end{array}$ \\
\hline
\end{tabular}

\section{Implementasi dan Evaluasi}

Produk berupa Media Audio Visual Tema berbasis cerita dan lagu anak, tahap selanjutnya adalah evaluasi ahli yang bertujuan untuk memberikan penilaian kritik, dan saran tentang media dan materi. Dalam uji kelayakan media ini terdapat dua tahap, yaitu tahap uji kelayakan teoritis dan uji kelayakan empiris. Uji kelayakan teori melibatkan para ahli (expert evaluation) yang ahli di bidangnya, sedangkan uji kelayakan empiris melibatkan siswa sebagai pengguna (uji skala kecil dan uji skala besar). Pada setiap tahapan dilakukan revisi terhadap media audio visual lagu dan cerita anak berbasis tema yang dievaluasi berdasarkan masukan dari validator.

\section{Uji Kelayakan Teori Media}

Evaluasi Ahli atau produk awal dilakukan untuk mengevaluasi produk awal sebagai masukan perbaikan dengan melakukan analisis yang kemudian direvisi. Tenaga ahli yang menilai produk awal ini terdiri dari (dua) orang yang memiliki keahlian dalam materi buku panduan stimulasi dan deteksi dini untuk tumbuh kembang anak usia dini dan bidang media. Pada tabel 2 adalah daftar para ahli (expert evaluation).

Media ini dilakukan dengan memperkenalkan prototipe awal media audio visual berbasis tema untuk cerita dan lagu anak dengan format Video yang diunggah di Google Drive. Lembar observasi berupa angket berisi pertanyaan terkait media dengan aspek penilaian: Kelayakan isi, penyajian bahasa, tampilan. Hasil evaluasi berupa nilai dan saran dari para ahli terhadap produk yang telah dikembangkan. 
Tabel 2 Daftar Nama Ahli (expert evaluation)

\begin{tabular}{clcl}
\hline No. & \multicolumn{1}{c}{ Nama } & Bidang Ahli & \multicolumn{2}{c}{ Afiliasi } \\
\hline 1 & Dr. Yosef, M.A & Ahli Media & Universitas Sriwijaya,Indonesia, Counseling Guidance Lecturer \\
2 & Fachrul Rozi, & Ahli Materi & Universitas Mulawarman, Indonesia, lecturer in Early \\
& S.Pd., M.Pd & & Childhood Education Program \\
\hline
\end{tabular}

\section{Evaluasi Ahli Materi Desain}

Tujuan dari evaluasi produk adalah untuk menguji kelayakan dan mengetahui pendapat tentang media audio visual berbasis tema cerita dan lagu anak yang dikembangkan serta untuk memperoleh informasi berupa perbaikan, kritik, dan saran terhadap produk yang telah dikembangkan. Hasil evaluasi ahli desain materi dapat dilihat pada tabel 3.

Tabel 3 Hasil Evaluasi Ahli Desain Materi

\begin{tabular}{llc}
\hline No & Indikator & Kuisioner Kelayakan Nilai Setiap Aspek \\
\hline 1 & Kelayakan Isi & $43,75 \%$ \\
2 & Penyajian Bahasa & $23,75 \%$ \\
3 & Penampilan & $28,75 \%$ \\
\multicolumn{2}{l}{ TOTAL } & $96,25 \%$ \\
\hline
\end{tabular}

Kesimpulan Penilaian Ahli Media pada media audio visual cerita dan lagu anak berbasis tema yang telah dikembangkan berdasarkan rumus adalah nilai persentase kelayakan produk sebesar 96,25\% dikategorikan produk sangat valid dan dapat digunakan dengan sedikit revisi. Ahli media memberikan masukan berupa kelebihan dan kekurangan sehingga media yang dikembangkan harus direvisi dan diperbaiki. Berikut penjelasan kelebihan dan kekurangan produk yang diberikan oleh ahli media.

\section{Tabel 4 Kelebihan dan Kekurangan dari Hasil Valdiasi}

\begin{tabular}{|c|c|}
\hline Kelebihan & Kekurangan \\
\hline $\begin{array}{l}\text { Produk yang dikembangkan menarik } \\
\text { sesuai kebutuhan orang tua dan guru } \\
\text { Cerita dan lagu anak berbasis tema } \\
\text { dikembangkan sesuai karakteristik anak } \\
\text { Cerita dan tema sangat menarik }\end{array}$ & $\begin{array}{l}\text { Materinya sangat bagus, namun sebaiknya } \\
\text { kegiatan menggambar disesuaikan dengan } \\
\text { media lukis yang disajikan dalam video }\end{array}$ \\
\hline
\end{tabular}

\section{Evaluasi oleh Ahli Media}

Tujuan dari uji coba ahli ini adalah untuk mengetahui kelayakan produk media audio visual berbasis tema lagu dan cerita anak untuk dikoreksi, memberikan saran, masukan dengan mengevaluasi dan merevisi media yang terdapat pada produk video yang dikembangkan. Hasil evaluasi ahli media audio visual berbasis tema cerita dan lagu anak berdasarkan instrumen angket pengembangan produk disajikan pada tabel 5 .

Tabel 5 Hasil Evaluasi Ahli Media

\begin{tabular}{clc}
\hline Nomor & \multicolumn{1}{c}{ Indikator } & Skor Kelayakan Angket untuk setiap aspek \\
\hline 1 & Media Visual & $25 \%$ \\
2 & Media Audio & $18,18 \%$ \\
3 & Aspek Tipografi & $15,90 \%$ \\
4 & Aspek Bahasa & $9,09 \%$ \\
5 & Aspek Pemrograman Media & $25 \%$ \\
\hline \multicolumn{2}{c}{ Total } & $93,17 \%$ \\
\hline
\end{tabular}


Kesimpulan penilaian ahli media audio visual tentang cerita dan lagu anak berbasis tema pada keseluruhan produk telah dikembangkan berdasarkan rumus nilai persentase kelayakan produk sebesar 93,17\% dengan kategori sangat valid, maka hal ini produk dapat digunakan dan dilanjutkan ke uji coba kelompok kecil. Ahli media memberikan masukan berupa kelebihan dan kekurangan produk yang dikembangkan sehingga produk yang dikembangkan masih perlu diperbaiki dan direvisi. Tabel 6 disajikan kelebihan dan kekurangan yang diberikan oleh ahli media.

Table 6 Masukan dan Saran dari Ahli Media

\begin{tabular}{ll}
\hline \multicolumn{1}{c}{ Kelebihan } & \multicolumn{1}{c}{ Kekurangan } \\
\hline Kerangka media benar & Jika memungkinkan Dimas animasi dan \\
& ibunya disertai dengan gerakan tangan \\
Media disajikan sesuai dengan materi & Tangan dan kaki secara proporsional \\
$\begin{array}{l}\text { yang akan dikembangkan pada anak } \\
\text { usia dini }\end{array}$ & Untuk merangsang persepsi motorik anak \\
\end{tabular}

\section{Pembahasan}

Berdasarkan hasil validasi materi di atas, produk media audio visual berbasis tema untuk cerita anak sangat valid, hal ini sejalan dengan pendapat Luthfiyah \& Fitrah (2017) validitas isi merupakan instrumen yang dapat digunakan untuk mengukur prestasi belajar dan mengukur efektivitas pelaksanaan program dan tujuan, mengembangkan instrumen pencapaian pembelajaran yang memiliki validitas isi, instrumen harus disusun berdasarkan materi pelajaran yang akan diajarkan. Senada dengan Arikunto (2018), validitas konstruk adalah validitas konstruk yang dilakukan dengan memasangkan dan merinci setiap aspek indikator. Berdasarkan hasil penelitian Anggraini (2016) bahwa persentase keseluruhan ahli materi harus lebih dari $80 \%$ dikatakan layak dan valid untuk digunakan sebagai bahan pendukung media pembelajaran yang dikembangkan.

Teknologi sangat berpengaruh dan memiliki dampak terhadap anak. Berdasarkan perhitungan persentase lebih dari 50\% administrator dan guru mengungkapkan bahwa 5 hari dalam satu pecan anak dapat berinteraksi dan menggunakan tekonologi dalam pembelajaran, adapun tingkat presentase berinteraksi dengan teknologi satu kali dalam sepekan hanya mencapai 10\% (Suryana \& Hijriani, 2021). Dengan begitu terlihat bahwa teknologi yang digunakan dalam pembelajaran dapat mempengaruhi hasil belajar anak yang merupakan dampak dari penggunaannya sebagai media maupun bahan belajar. Terlebih lagi pada masa pandemic covid-19, penggunaan media pembelajaran yang berbasis teknologi sangat dibutuhkan guna mengatasi keterbatasan ruang dan waktu.

Video pembelajaran merupakan media yang dapat menampilkan unsur suara dan gambar bergerak atau media yang dapat dilihat dan didengar (Jatmiko \& Wijayantin, A Susilaningsih, 2017; Novita et al., 2019). Media yang dikembangkan harus memperhatikan usia anak, perkembangan psikologis dan kebutuhan spesifik anak sebagai individu yang unik (Yuliani et al., 2017). Media pembelajaran berupa suara, gambar, animasi, dan video dapat digunakan sebagai media pembelajaran visual. Melalui video, anak-anak dapat melihat aksi nyata dalam video sehingga, pesan dalam video tersampaikan dan dapat memotivasi siswa dalam belajar (Munawar et al., 2020; Naharir et al., 2018; Yudha et al., 2017). Dalam menstimulasi aspek perkembangan anak, dibutuhkan semua media pembelajaran yang nyata sehingga anak pembelajarannya dapat berjalan secara efektif (Ismawati \& Prasetyo, 2020). Maka hal tersebut menjadi salah satu penunjang pengimplementasian media pembelajaran berupa video, terlebih lagi yang di dalamnya memuat cerita dan lagu anak.

Peran media pembelajaran sangatlah penting, salah satunya yaitu sebagai alat perantara yang dapat menstimulasi pikiran, minat, perasaan dan perhatian anak dalam kegiatan belajar yang nantinya dapat terkendali dan konsep yang diberikan dapat diterima oleh anak (Apriliani et al., 2020; Ariani \& Ujianti, 2021; Nur Hidayah \& Nurhadija, 2018; Nursafitri et al., 2021; Syafi'i 
et al., 2020). Pemberian desain yang menarik menjadi salah satu faktor untuk menstimulasi perhatian anak sehingga akan menimbulkan fokus, adapun lagu dan cerita merupakan variasi yang memiliki nilai untuk menstimulasi pikiran, kemauan dan perasaan anak untuk memahami sesuatu secara sederhana dan menyenangkan.

Animasi yang digunakan dalam video selain menarik perhatian anak, namun hal tersebut memberikan sebuah informasi terhadap anak mengenai benda nyata yang dapat dilihat secara virtual. Adapun animasi adalah karakter yang dihidupkan sehingga yang awal mulanya diam menjadi bergerak (Antika et al., 2019; Awalia et al., 2019; Prahesti et al., 2019). Dalam video menayangkan berbagai animasi yang bergerak seperti ketika adanya dua tokoh yang bertemu, sehingga menciptakan sebuah realitas visual yang mengurangi faktor monoton. Komponen utama dalam video berupa cerita dan lagu anak yang dikemas menggunakan visual karakter dan dipadukan dengan audio sebuah kombinasi yang dapat memunculkan pembelajaran secara efektif, informatif dan menarik bagi anak (Ariani \& Ujianti, 2021; Lukman et al., 2019; Muslina et al., 2018; Panjaitan et al., 2020; W. D. Putri \& Fitria, 2021). Ketika anak belajar sesuatu yang menarik maka akan melekat dalam long term memory, pengalaman yang didapat anak diperoleh dari indra pendengaran sebesar 13\% dan indra penglihatan sebesar $75 \%$, sedangkan 12\% lainnya melalui indra lainnya (Apriansyah, 2020; Murti \& Anas, 2020). Hal tersebut menjadi sebuah keunggulan tersendiri bagi media pembelajaran yang memadukan antara audio visual berbatuk video yang terdiri dari karakter animasi bergerak.

Kelebihan media video pembelajaran adalah 1) merupakan media yang memadukan gambar dan suara, 2) mampu mempengaruhi perilaku manusia jika dibandingkan dengan media cetak, 3) dapat digunakan secara praktis melalui komputer, laptop atau smartphone, 4) dapat menyajikan objek secara detail, 5) dapat menghadirkan objek berbahaya, 6) efisiensi waktu, dan 7) dapat digunakan untuk klasik atau individu Agustiningsih (2015).

\section{SIMPULAN}

Hasil pengembangan cerita dan lagu rumah sederhana sangat valid dengan memperoleh persentase sebesar $96,25 \%$ dan hasil validasi media dari validator memperoleh nilai persentase sebesar $93,17 \%$ dengan kategori sangat valid sehingga hasil rata-rata media validasi dan validasi materi memperoleh nilai persentase sebesar 94,71\% dengan kategori sangat valid artinya media audio visual cerita dan lagu rumah sederhana untuk anak usia dini sangat valid untuk diujikan dan diimplementasikan pada subjek penelitian ditinjau dari media visual, audio, bahasa, pemrograman, tampilan dan kelayakan konten. Dengan demikian video cerita dan lagu rumah sederhana layak untuk di terapkan oleh guru dan orang tua di rumah dalam menstimulasi perkembangan bahasa anak khususnya dalam memberikan stimulasi berbicara.

\section{UCAPAN TERIMA KASIH}

Penulis mengucapkan terima kasih kepada berbagai pihak yang telah membantu dalam penyelesaian penelitian dan artikel ini. Kepada UPPM FKIP Universitas Sriwijaya yang telah memberikan dukungan, kepada rekan-rekan serta kepada tim mitra dari Universitas Mulawarman dan kami mengucapkan terima kasih kepada Pengelola Jurnal Obsesi yang telah membantu proses penerbitan artikel ini.

\section{DAFTAR PUSTAKA}

Agustiningsih. (2015). Video Sebagai Alternatif Media Pembelajaran Dalam Rangka Mendukung Keberhasilan Penerapan Kurikulum 2013 Di Sekolah Dasar. Pancaran Pendidikan. 4(1). https:// doi.org/10.21070/pedagogia.v4i1.72

Anggraini, F. (2016). Pengembangan Alat Peraga Sistem Pernapasan Manusia Berbasis Barang Bekas Pada Siswa SMP N 1 Bandar Lampung. Jurnal : Bandar Lampung. FKIP Biologi Lampung, 1(1), 20-21. 
Antika, H., Priyanto, W., \& Purnamasari, I. (2019). Pengaruh Penggunaan Media Animasi Sandisko Dengan Model Somatic Auditory Visualization Intellectually Terhadap Hasil Belajar Tema Kebersamaan Kelas 2. Mimbar Ilmu, 24(2), 247. https:// doi.org/10.23887/mi.v24i2.21288

Apriansyah, M. R. (2020). Pengembangan Media Pembelajaran Video Berbasis Animasi Mata Kuliah Ilmu Bahan Bangunan Di Program Studi Pendidikan Teknik Bangunan Fakultas Teknik Universitas Negeri Jakarta. Jurnal PenSil, 9(1), 9-18. https:// doi.org/10.21009/jpensil.v9i1.12905

Apriliani, E. I., Purwanti, K. Y., \& Riani, R. W. (2020). Peningkatan Kesantunan Bahasa Anak Usia Dini melalui Media Pembelajaran Interaktif Budaya Jawa. Jurnal Obsesi : Jurnal Pendidikan Anak Usia Dini, 5(1), 150. https://doi.org/10.31004/obsesi.v5i1.319

Ariani, N. K., \& Ujianti, P. R. (2021). Media Video Animasi untuk Meningkatkan Listening Skill Anak Usia Dini. Jurnal Pendidikan Anak Usia Dini Undiksha, 9(1), 43. https:// doi.org/10.23887/paud.v9i1.35690

Arikunto, S. (2018). Prosedur Penelitian: Suatu Pendekatan Praktik. Jakarta: Rineka Cipta.

Awalia, I., Pamungkas, A. S., \& Alamsyah, T. P. (2019). Pengembangan Media Pembelajaran Animasi Powtoon pada Mata Pelajaran Matematika di Kelas IV SD. Kreano, Jurnal Matematika Kreatif-Inovatif, 10(1), 49-56. https:// doi.org/10.15294/kreano.v10i1.18534

Fiah, R. . (2017). Bimbingan Dan Konseling Anak Usia Dini. Jakarta: PT Raja Grafindo Persada. Ismawati, D., \& Prasetyo, I. (2020). Efektivitas Pembelajaran Menggunakan Video Zoom Cloud Meeting pada Anak Usia Dini Era Pandemi Covid-19. Jurnal Obsesi : Jurnal Pendidikan Anak Usia Dini, 5(1), 665. https:// doi.org/10.31004/obsesi.v5i1.671

Jatmiko, P. D., \& Wijayantin, A Susilaningsih, S. (2017). Pengaruh Pemanfaatan Video Pembelajaran Terhadap Hasil Belajar Ipa Kelas Iv Sekolah Dasar. Edcomtech Jurnal Kajian Teknologi Pendidikan, 1(2), 153-156. https:// doi.org/10.22437/gentala.v2i1.6822

Lukman, A., Hayati, D. K., \& Hakim, N. (2019). Pengembangan Video Animasi Berbasis Kearifan Lokal pada Pembelajaran IPA Kelas V di Sekolah Dasar. Elementary: Jurnal Ilmiah Pendidikan Dasar, 5(2), 153. https://doi.org/10.32332/elementary.v5i2.1750

Luthfiyah, \& Fitrah, M. (2017). Metodologi Penelitian; Penelitian Kualitatif, Tindakan Kelas \& Studi Kasus. Sukabumi: CV Jejak.

Munawar, B., Farid Hasyim, A., \& Ma'arif, M. (2020). Pengembangan Bahan Ajar Digital Berbantuan Aplikasi Animaker Pada PAUD Di Kabupaten Pandeglang. Jurnal Golden Age, 4(02), 310-320. https:// doi.org/10.29408/iga.v4i02.2473

Murti, W., \& Anas, M. (2020). Penerapan Pola Pemberdayaan Berpikir Melalui Pertanyaan dalam Model Pembelajaran Two Stay Two Stray untuk Meningkatkan Aktivitas dan Hasil Belajar pada Mata Kuliah Mikrobiologi Terapan. Biology Teaching and Learning, 2(2), 101-113. https:// doi.org/10.35580/btl.v2i2.12012

Muslina, M., Halim, A., \& Khaldun, I. (2018). Kelayakan Media Animasi Hukum Newton Ii Tentang Gerak Pada Bidang Miring Dan Katrol Di Sma Kabupaten Aceh Besar. Jurnal IPA \& Pembelajaran IPA, 1(1), 64-72. https:// doi.org/10.24815/jipi.v1i1.9568

Naharir, Dantes, \& Kusmariyatni. (2018). Pengaruh Model Pembelajaran Course Review Horay Berbantuan Media Video Pembelajaran Terhadap Hasil Belajar Matematika Siswa Kelas V Semester II SD Gugus VI Kecamatan Sukasada Kabupaten Buleleng Tahun Pelajaran 2017/2018. Mimbar PGSD Undiksha. 6(1), 15-21.

Novita, Sukmanasa, \& Pratama. (2019). Penggunaan Media Pembelajaran Video Terhadap Hasil Belajar Siswa SD. . Indonesian Journal of Primary Education, 3(2), 65-72.

Nur Hidayah, A., \& Nurhadija, N. (2018). Aktivitas Mendongeng Menggunakan Media Audio Visual Dalam Pembelajaran Moral. Jurnal Smart Paud, 1(1), 73. https://doi.org/10.36709/jspaud.v1i1.3523 
Nursafitri, L., Purwanti, E., \& Fitriyah, F. (2021). Pelatihan Video Pembelajaran Kreatif di Era New Normal bagi Guru PAUD di Kecamatan Tanjung Bintang, Lampung Selatan. Abdimas: Jurnal Pengabdian Masyarakat Universitas Merdeka Malang, 6(1), 35-42. https://doi.org/10.26905/abdimas.v1i1.4919

Panjaitan, N. Q., Yetti, E., \& Nurani, Y. (2020). Pengaruh Media Pembelajaran Digital Animasi dan Kepercayaan Diri terhadap Hasil Belajar Pendidikan Agama Islam Anak. Jurnal Obsesi : Jurnal Pendidikan Anak Usia Dini, 4(2), 588. https://doi.org/10.31004/obsesi.v4i2.404

Prahesti, S. I., Taulany, H., \& Dewi, N. K. (2019). Gerak dan Lagu Neurokinestetik (GELATIK) untuk Menumbuhkan Kreativitas Seni Anak Usia Dini. Jurnal Obsesi: Jurnal Pendidikan Anak Usia Dini, 4(1), 162. https://doi.org/10.31004/obsesi.v4i1.289

Putri, H. (2017). Konsep Pendidikan Anak Usia Dini Dalam Perspektif Islam. Khazanah: Jurnal $\begin{array}{llll}\text { Studi Islam Dan Humaniora, } & 13(2),\end{array}$ https://doi.org/10.18592/khazanah.v14i2.1634

Putri, W. D., \& Fitria, N. (2021). Pengaruh Video Pembelajaran Cerita Dan Lagu Terhadap Kemampuan Berbicara Anak. Jurnal Anak Usia Dini Holistik Integratif (AUDHI), 2(2), 102. https:// doi.org/10.36722/jaudhi.v2i2.585

Rakimahwati, R., Ismet, S., \& Roza, D. (2021). Studi pengembangan Psikolinguistik Anak dengan Game Interaktif Berbasis Role Playdi Taman Kanak-kanak Fadhillah Amal 3 Kota Padang. Jurnal Obsesi : Jurnal Pendidikan Anak Usia Dini, 6(3), 1955-1964. https://doi.org/10.31004/obsesi.v6i3.934

Rusniah, R. (2017). Meningkatkan Perkembangan Bahasa Indonesia Anak Usia Dini Melalui Penggunaan Metode Bercerita Pada Kelompok A Di Tk Alahayati Neuhen Tahun Pelajaran 2015/2016. Jurnal Edukasi: Jurnal Bimbingan Konseling, 3(1), 114. https://doi.org/10.22373/je.v3i1.1445

Suryana, D., \& Hijriani, A. (2021). Pengembangan Media Video Pembelajaran Tematik Anak Usia Dini 5-6 Tahun Berbasis Kearifan Lokal. Jurnal Obsesi : Jurnal Pendidikan Anak Usia Dini, 6(2), 1077-1094. https:// doi.org/10.31004/obsesi.v6i2.1413

Syafi'i, I., Sa'diyah, C., Wakhidah, E. W., \& Umah, F. M. (2020). Penerapan Video Pembelajaran DaringAnak Usia Dini Pada Masa Pandemi Covid 19. Al-Athfaal: Jurnal Ilmiah Pendidikan Anak Usia Dini, 3(2), 140-160. https:// doi.org/10.24042/ajipaud.v3i2.7315

Wati, P. (2018). Pengembangan Buku Cerita Bergambar Berdasarkan Lagu-Lagu Berbahasa Jawa sebagai Media Penanaman Nilai Karakter Anak Usia Dini di Kabupaten Pemalang. Piwulang: Jurnal Pendidikan Bahasa Jawa, 8(1), 46-53. https:// doi.org/10.15294/piwulang.v8i1.15959

Widjanarko, P. (2017). Pendidikan Seni Bermain Dan Bernyanyi Anak Usia Dini. JURNAL AUDI: Jurnal Ilmiah Kajian Ilmu Anak Dan Media Informasi PAUD, 1(1). https:// doi.org/10.33061/ad.v1i1.1206

Yudha, Pudjawan, \& Tegeh. (2017). Pengembangan Video Matembang Sekar Alit Berbasis Model Direct Instruction DI SMP Negeri 5 SINGARAJA. Jurnal Edutech Undiksha, 5(1), 19-27.

Yuliani, Antara, \& Magta. (2017). Pengaruh Video Pembelajaran Terhadap Kemampuan Berhitung Permulaan Anak Kelompok B Di Taman Kanak-Kanak. Jurnal Pendidikan Anak Usia Undiksha, 5(1), 96-106. 